Latarnia od Sw. Walentego pochodzi z XIV w. Wykonana z piaskowca, ma kzstałt sześciokątnego graniastosłupa o wysokości $6 \mathrm{~m}$. Nakryta była piramidalnym daszkiem, nad którym widniał krzyż. Przed frontem kościoła Sw. Walentego latarnia stała na znacznym podwyższeniu-cokole, dzięki czemu była bardziej widoczna. W górnej swej części jest ozdobiona ślepym gotykiem rozetowaniem wspartym na pionowych żebrach. Dzisiaj lampa ma zamurowane wszystkie zewnętrzne otwory w ścianach, przez które kiedyś światło przedostawało się na zewnątrz, wskutek czego znikła jej pełna wdzięku ażurowość.

Obecnie latarnia usytuowana na dawnym cmentarzu przykościelnym przy ul. Kopernika - na skutek podniesienia nawierzchni ulicy spowodowanego względami komunikacyjnymi oraz $z$ powodu braku cokołu - jest znacznie niższa i mało widoczna. Niemniej jednak tym, którzy przenieśli ją na obecne miejsce, przyświecała myśl, by ten piękny przedmiot $\mathrm{z}$ dawnej przeszłości dalej służył żywym, by przypominał im o tych, którzy odeszli, by pobudzał ich do modłów za ich dusze.

Latarnia od Św. Walentego jest unikalnym zabytkiem nie tylko Krakowa, ale i całego kraju.

Kraków

KS. JAN KUS

\begin{tabular}{llllllllllllll}
$S$ & $P$ & $R$ & $A$ & $W$ & $O$ & $Z$ & $D$ & $A$ & $N$ & I & $A$ \\
\hline
\end{tabular}

\title{
Z DZIALALNOŚCI POLSKIEGO TOWARZYSTWA TEOLOGICZNEGO W KRAKOWIE W ROKU 1985
}

\section{STAN TOWARZYSTWA}

1.1. W a l ne Z e bra nie odbyło się dnia 13 II 1985 r. o godz. 16.15.

1.2. Z a r ząd. Na Walnym Zebraniu wybrano następujący Zarząd:

prezes -

wiceprezes -

sekretarz -

skarbnik -

bibliotekarz - ks. doc. dr hab. Jerzy Chmiel

o. dr Jan Wichrowicz OP

ks. lic. Antoni Okrzesik

ks. mgr Stanisław Żychowicz

(po jego rezygnacji, od 12 VI 1985)

ks. Zbigniew Gerle

ks. lic. Jan Bednarczyk

(dokooptowany przez Zarząd) 
W okresie sprawozdawczym Zarząd odbył cztery posiedzenia:

8 III 1985; 12 VI 1985; 25 X 1985; 1 3XII 1985.

1.3. Komisja Kontrolująca została wybrana w składzie: przewodniczący - ks. dr Kazimierz Waliczek

członkowie: ks. dr Jan Dyduch i ks, dr Stefan Rykko CRL

1.4. Są d Koleżeński wybrano w składzie:

przewodniczący - ks. doc. dr hab. Adam Kubiś

członkowie - ks. dr Stefan Cichy i ks. dr Stanisław Bizuń

1.5. Członkowie. Stan członków Towarzystwa na dzien 31 XII 1985: zwyczajnych: 266, wspierających: 32 , razem: 298. W roku sprawozdawczym przyjęto 12 nowych członków zwyczajnych: ks. mgr Antoni Pawlita, ks. Jan Zając, ks. lic. Jan Bednarczyk, ks. mgr Janusz Wycisło, ks. Alojzy Wencepel, ks. Zbigniew Gerle, ks. mgr Kazimierz Moskała, ks. mgr Jan Kaczmarek, ks. dr Tadeusz Biesaga SDB, O. Wojciech Giertych OP, ks. mgr Kazimierz Grela, ks. mgr Adam Podbiera.

Godności i odznaczenia.

Ks. dr Damian Zimoń został biskupem ordynariuszem katowickim. O. prof. dr hab. Augustyn Jankowski OSB otrzymał benedykcję opata w Tyńcu.

Ks. Bp prof. dr hab. Marian Jaworski, rektor PAT w Krakowie, otrzymal list gratulacyjny Towarzystwa $z$ okazji nadania mu doktoratu h.c. przez Ruhr-Universität w Bochum.

Członek wspierający dr Stanisław Waliszewski został odznaczony przez Towarzystwo medalem komemoratywnym w 50-lecie praktyki lekarskiej za ponad 40-letnią działalność popularyzacyjno-naukowa na polu syndonologii w Polsce.

Zmarli czlonkowie.

Ks. dr Stanisław Wójtowicz, ks. lic. Władysław Włodarski, ks. dr Janusz Nanowski, ks. Antoni Kowalski, ks. Franciszek Gancarczyk, ks. doc. dr hab. Józef Brudz, o. dr Jan Wojnowski CSsR, ks. mgr Adam Skrzypiec, o. dr Bolesław Celiński CSsR, o. dr Albert Urbański OC, ks. Władysław Maćkowski, ks. dr Stanisław Bista R.i.p.

\section{DZIAEALNOŚĆ ODCZYTOWA TOWARZYSTWA}

2.1. Sekcyjne zebrania naukowe

2.1.1. Sekcja filozoficzna. Kierownik: ks. doc. dr hab. Henryk Piszkalski CSsh. Trzy zebrania z referatami:

22 X 1985: ks. dr hab. Henryk Piszkalski, Romano Guardini $w$ cbronie życia człowieka od samego poczatku - argumentacja filozoficzna; 
19 XI 1985: ks. prof. dr hab. Jan Sieg SI, Filozoficzne inspiracje teologit wyzwolenia;

17 XII 1985: tenże, Ideologiczny charakter teologii wyzwolenia. 2.2.2. Sekcja biblijno-liturgiczna. Kierownik: ks. dr hab. Tomasz Jelonek. Trzy sesje $z$ referatami:

1) 13 II 1985 III sesja syndonologiczna, w czasie której wygłoszono następujące referaty:

- dr Stanisław Waliszewski: Calunowe echo w pierwszym tysiacleciu chrześcijaństwa na podstawie dokumentacji Mons. Pietro Savio,

- ks. doc. dr hab. Jerzy Chmiel: Swiadectwo Czwartej Ewangelii. Nowe propozycje egzegetyczne,

- komunikaty na temat badań Całunu w $1984 \mathrm{r}$.;

2) 24 IV 1985 sesja nt. „Bóg, który wyzwala” z referatami:

- ks. dr Tomasz Jelonek, Biblijna koncepcja wolności,

- ks. doc. dr hab. Jerzy Chmiel, Wyzwalajaca moc Boga $i$ dzialanie Tudzkie $w$ Starym Testamencie,

- 0 . prof. dr hab. Augustyn Jankowski OSB, Idea wyzwolenia $w$ soteriobogii św. Pawla;

3) $20 \mathrm{XI} 1985$ sesja poświęcona 20. rocznicy Konstytucji soborowej Dei verbum z referatami:

- o. dr Tomasz Dąbek OSB, Aktualne wartości Konstytucji Dei veroum,

- ks. lic. Stanisław Hałas SCJ, Żywe Słowo Boga według 1. Listu sw. Piatra,

- ks. dr hab. Tomasz Jelonek, Ujęcie prawdziwości Biblii wedlug Korstytucji Dei verbum.

2.2.3. Sekcj? apologetyczno-religioznawcza. Kierownik: ks. doc. àr hab. Adam Kubiś. Cztery zebrania z referatami:

22 III 1985: ks. prof. dr hab. Jan Sieg SI, Materializm historyczny a teologia wyzwolenia,

17 V 1985: ks. dr Jerzy Mrówczyński CR, Ks. Paweł Smolikowski - człowiek i myśliciel,

22 XI 1985: ks. dr Łukasz Kamykowski, Źródła kryzysu w Kościele w świetle "Raportu na temat wiary kard. Józefa Ratzingera”;

13 XII 1985: ks. prof. dr hab. Stanisław Nagy SCJ (KUL), Sprawozdanie z Nadzwyczajnego Synodu Biskupów w Rzymie 1985.

2.2.4. Sekcja dogmatyczno-moralna. Kierownik: o. dr Jan Wichrowicz OP. Sześć zebrań z referatami:

14 I 1985: o. dr Bogdan Brzuszek OFM, Casus o. Leonarda Boffa OFM;

11 II 1985: o. dr Cecylian Niezgoda OFMConv, Paula Zofia Tajber jako apostołka Ciała Mistycznego; 
11 III 1985: ks. doc. dr hab. Jan Kowalski, Moralny problem odstraszających zbrojeń nuklearnych w świetle dokumentów kościelnych i wypowiedzi teologów;

7 X 1985: ks. dr Jan Hojnowski SCJ, Teologia dziejów narodu $w$,,Wojnie żydowskiej" Józefa Flawiusza";

4 XI 1985: ks. prof. dr hab. Tadeusz Slipko SI, Wybrane zagadnienia bioetyki:

2 XII 1985: o. dr Władysław Skrzydlewski OP, Nowe elementy sytuacji $w$ etyce $i$ teologii moralnej na Zachodzie.

2.2.5. Sekcja historyczna. Kierownik: o. doc. dr hab. Marian Kanior OSB. Cztery zebrania $\mathrm{z}$ referatami:

15 V 1985: dr inż. arch. Jan Rączka, Miejsce sakralne $w$ architekturze;

23 X 1985: s. Teresa Ledóchowska OSU, Początki Urszulanek co mówia encyklopedie, a co mówia dokumenty?;

13 XI 1985: ks. dr Stanisław Piech, Problem emigracji w Galicji $w$ świetle źródeł kościelnych;

11 \ 1985: ks. dr Ludwik Piechnik SI, Akademia Wileńska $w$ okresie kryzysu 1655-1730.

2.2.6. Sekcja kanonistyczna. Kierownik: ks. doc. dr hab: Tadeusz Pieronek, Dwa zebrania z referatami:

12 III 1985: ks. prof. dr Eugenio Corecco (Fryburg Szw.), Kaplaństwo $w$ nowym Kodeksie Prawa Kanoniczego;

11. XII 1985: ks. doc. dr hab. Tadeusz Pieronek, Kierunki reformy Kurii Rzymskiej;

lis. dr hab. Jan Dyduch, Zadania i obowiazki świeckich $w$ świecie $i w$ Kościele $w g$ dokumentu VII Synodu Biskupów.

2.2.7. Sekcja misjologiczna. Kierownik: ks. doc. dr hab. Antoni Baciński CM. Dwa zebrania z referatami:

16 X 1985: ks. doc. dr hab. Antoni Baciński, Misyjne zastugi Papieża Piusa XI;

27 XI 1985: ks. mgr Jan Kaczmarek CM, Moje wrażenia z pracy misyjnej $w$ Zairze.

2.2.8. Sekcja w Kalwarii Zebrzydowskiej. Kierownik: o. dr Wiesław Murawiec OFMBern. Dwa zebrania i jedno sympozjum:

15 II 1985: o. dr Letus Szpucha, Eucharystia wg nowego Kodeksu Prawa Kanonicznego;

24 V 1985: mgr Jerzy Stobiński, Wybrane zagadnienia z zakresu psychologii;

25 IV 1985: sympozjum ku czci błog. Szymona z Lipnicy z referatami. 
2.2.9. Sekcja w Tarnowie. Kierownik: ks. dr Michał Bednarz. Cztery zebrania $\mathrm{z}$ referatami:

30 IV 1985: ks. dr hab. Wojciech Kania, Pismo św. w posłudze pasterskiej św. Jana Chryzostoma;

22 X 1985; ks. dr hab. Leopold Regner, Sofizmaty jako rodzaj dysputy scholastycznej;

7 XI 1985: ks. prof. dr hab. Bolesław Kumor, Więź Diecezji Tarnowskiej z Kościołem Polskim $w$ okresie germanizacji austriackiej;

7 XIl 1985: ks. prof. dr hab. Stanisław Grzybek, Najświętsza Maryja Panna $w$ Biblii.

2.2.10 Sekcja w Tuchowie. Kierownik: o. mgr Stanisław Bafia CSsR. Zebranie i sypmozjum z referatami:

23 III 1985: ks. prof. dr hab. Józef Kudasiewicz (KUL), Pojęcie cudu i chrystologiczna interpretacja cudów ewangelicznych;

26-28 IX 1985: o .dr M. Nalepa, Wartości teologiczne $i$ duszpasterskie kultu maryjnego;

- o. prof. dr hab. S. Napiórkowski (KUL), Główne nurty wspótczesnej mariologii;

- tenże, Mariologiczne błędy $w$ pieśniach maryjnych;

- o. dr S. Madeja, Kult maryjny $w$ świetle „Marialis cultus”;

- o. mgr K. Smoleń, Struktura nabożeństwa Nieustannej Nowen$n y$;

- ks. prof. dr hab. Cz. S. Bartnik (KUL), Charakterystyczne aspekty mariologii polskiej;

- tenże, Maryja Matka rodziny i narodu.

2.2.11. Sekcja w Katowicach. Kierownik: ks. dr Stefan Cichy. Pięc zebrań z referatami:

20 III 1985: ks. dr Jerzy Myszor, Miejsce Jasnej Góry w pobożności ludu górnoślaskiego $w$ XIX i na poczatku XX wieku;

16 IV 1985: ks. doc. dr hab. Romuald Rak, Kobieta - partnerka $w$ Kaściele. Sprawozdanie $z$ Wiedeńskich Dni Pastoralnych 1984;

24 IV 1985: ks. mgr Janusz Wycisło, Czasopismo „Praca” i propagowany $w$ nim model robotnika chrześcijańskiego;

$8 \mathrm{~V}$ 1985: ks. prof. dr hab. Bolesław Kumor, Podstawy historyczne kultu Najświętszej Maryi Panny w Polsce;

20 XI 1985: ks. dr Stefan Cichy, Idee przewodnie posoborowej odnowy liturgicznej.

2.2. Zebrania okolicznościowe

Z okazji 100-lecia urodzin Juliusza Osterwy odbyło się 18 VI 1985 uroczyste zebranie pod patronatem JEm Ks. Kardynała Franciszka Macharskiego. Na Jego ręce Papież Jan Paweł II przysłał list okolicznościowy. Referat wygłosil dr Ireneusz Guszpit (Wrocław): Juliusza Osterwy myśl o teatrze religijnym. 
2.3. Odczyty publiczne

W ramach cyklu „Jan Pawel II naucza":

1) 28 II 1985: ks. doc. dr hab. Jerzy Chmiel, Jerozolima - święte dziedzictwo wszystkich wierzacych w Boga (omówienie listu apostolskiego Jana Pawła II);

2) 14 III 1985: ks. doc. dr hab. Jerzy Chmiel, O pojednaniu $i$ pokucie $w$ dzisiejszym posłannictwie Kościoła (nowa adhortacja apostolska Jana Pawta II);

3) 28 III 1985: ks. dr Tomasz Jelonek, Orędzie Ojca świętego na progu Międzynarodowego Roku Młodzieży;

4) 25 II i 4 III 1985: ks. doc. dr hab. Jerzy Chmiel, dwie konferencje na temat adhortacji Jana Pawła II o pojednaniu i pokucie w dzisiejszym posłannictwie Kościoła.

\section{WYDAWNICTWA}

Sekcja Wydawnicza Towarzystwa w okresie sprawozdawczym wydała:

- 6 zeszytów dwumiesięcznika ,Ruch Biblijny i Liturgiczny”,

- 2 roczniki „Analecta Cracoviensia”, tomy XVI i XVII,

- 9 pozycji książkowych.

IV. LIST WALNEGO ZEBRANIA DO PAPIEŻA JANA PAWEA II OJCZE SWIETY!

Uczestnicy Walnego Zebrania Polskiego Towarzystwa Teologicznego w Krakowie przesyłają Waszej Świątobliwości wyrazy czci, miłości i oddania.

Dziękujemy Ci, Ojcze Święty, za wszystkie Twoje słowa nauki, a szczególnie za ostatnią adhortacje apostolską RECONCILIATIO ET PAENITENTIA, którą czynimy przedmiotem osobnego studium. Zanosząc do Boga modlitwy w Twojej, Ojcze Swięty, intencji, prosimy Cię o Apostolskie Błogosławieństwo.

Kraków, dnia 13 lutego 1985 r.

Następują podpisy zebranych

(Opracowano na podstawie sprawozdania prezesa na Walne Zebranie) 